\title{
Evaluation of Post-Merger Performance of Public Listed Companies in the UK
}

\author{
XiaojiaoYe \\ International Business School \\ Yunnan University of Finance and Economics \\ 997463214@qq.com
}

\author{
Ying Zhang* \\ 1. School of Management and Marketing \\ Charles Sturt University \\ Wagga Wagga, Australia \\ 2. International Business School \\ Yunnan University of Finance and Economics \\ Kunming, China \\ angie@ynufe.edu.cn
}

\begin{abstract}
The objective of this study is to examine whether merger creates value for shareholders in short run. This study is based on a near-exhaustive sample of UK public listed companies during 1993 and 2000, total of 237 takeovers. The acquirers are UK based companies. Results show that merger and acquisitions do create value for target companies, and shareholders of acquiring firm earn negative abnormal returns. The results for short run Cumulative abnormal returns (CARs) indicate that the stocks market is inefficient. And under inefficient market, merger and acquisitions do create value for shareholders of bidders when the payment method is appropriately chosen.
\end{abstract}

Keywords-Post-merger performance; Merger and acquisitions; Value creation; Cumulative Abnormal Returns (CARs); UK stock market

\section{INTRODUCTION}

Merger and acquisitions has always been an interesting field in finance. And researchers as well as investors are particularly interested in the wealth creation for shareholders in both target and acquiring firms. As merger and acquisition activities are taking place more frequently, more empirical studies appear to evaluate such performance. And a general conclusion has been made that target firm shareholders receive large abnormal returns and are statistically significant (Jensen and Ruback, 1983). However, abnormal returns for shareholders of bidding firm are negative and close to zero (Mueller, 1985;Loughran and Vijh, 1997; Antoniou et al., 2008).

Value creation for shareholders is the most important attraction behind merger and acquisition activity. And how the value is realized in the short run is the main aim to achieve in this study.

This paper will focus on the performance of target and acquiring firms in the short run using CARs. In particular, it studies 237 merger announcement registered during 1993 and 2000 , and the share price performance of bidders and target companies were examined in this period around the announcement date. Event window of 5 days and 21 days

\footnotetext{
*Corresponding author
}

are taken for the short run performance.

\section{LITERATURE REVIEW}

\section{A. Value Creation for Shareholders}

\section{1) Returns for Target Company}

Bruner (2002) summarises more than 100 research papers on mergers and acquisitions value creation, from 1971 to 2001 . He concludes that merger and acquisition activities create value for target company to some extent ,but such gains should be treated rationally.

In general, shareholders of target firm receive significant positive returns. Further examples can be found in the findings of Dodd and Ruback (1977), Kummer and Hoffmeister (1978), Jarrell and Bradley (1980) [3],Asquith, Bruner, and Mullins (1983), [1] Bradley, Desai, and Kim (1988) and Franks and Harris (1989) [14]; all show positive and significant values created for target companies.

2) Returns for Acquiring Firm

Compared with the returns for shareholders of target firms, shareholders of acquiring firms normally receive negative or zero returns. In short, mergers and acquisition (M\&A) activities can deliver negative returns, positive returns, or no returns to acquiring firm shareholders. These types of returns are evenly distributed in the forty-four studies made by Bruner (2002) [6]. Each type presents around one-third of the distribution; thirteen studies show value deduction, fourteen studies show value conservation, and the remaining seventeen studies show value creation for shareholders.

Looking at the time line of post-merger performance, these studies show returns declining over time, with negative returns appearing to be smaller in the early studies than in the late 1980s. Only the technology and banking industries report increased returns in 1990s, marking exceptions to the general trend of this period.

A general conclusion can be made that acquiring firm shareholders receive only small positive, negative, or indeed zero returns. Limmack (1991) [22], Sudarsanam et al. [25] (1996), Kennedy [21] and Limmack (1996), Holl [20] and 
Kyriazis (1997), Gregory (1997) [17], and Higson and Elliott (1998) [19] provide evidence from the U.K., and evidence from the U.S. on such returns is provided by Weston (2001) et al [27].

\section{B. Payment method}

Merger activities can be paid in three ways; namely in cash, in stock, or in a mix of these two methods. The choice of payment method depends on the financial position of the acquiring firm, and on the target firm's preferences. The choice of payment form can affect post-merger performance in many ways.

\section{1) Cash payment}

Cash is preferred in the circumstances, which will now be explained. Information signaling theory suggests that if firms believe their stock is undervalued, signaling zero to positive information, cash would be preferred for merger activity (Travlos, 1987). More pertinently, excess cash held by a company can encourage cash payment in merger activities if no other investment opportunities are available. Further, if the acquiring firm has a low leverage level, they would offer cash for their activity. Moreover, as Faccio and Marsulis (2005) [9] illustrate, cash offers can protect the dominant control of shareholders rights. They analysis M\&A transactions in Europe listed companies from 1997 to 2000 , and find that there are around $63 \%$ shareholder's control above $20 \%$ vote. In contrast, in the U.S. market, only $28 \%$ of shareholders in publicly listed companies control $20 \%$ or more of their vote.

\section{2) stock payment}

Payment in the form of stock is usually used in the situations that shall be explained below. Stock is often used if a firm believes their stock is overvalued or properly valued, thus using stock provides negative information (Travlos, 1987). Rappaport and Sirower (1999) show that stock financing has, however, the opposite effect, and creates a negative image for an acquiring firm. Bidders with higher leverage level are only tax liable when the shares are sold, and there is a greater premium for a stock payment (DePamphilis, 2005) [8]. The performance of the share price has opposite effects if the merger is financed with stock, compare to its financing with cash.

\section{3) Mix of cash and stock}

Offers combining cash and stock can increase the likelihood of a successful offer, as both the advantages and the disadvantages of the two methods can be balanced. For example, shareholders of the target company might accept a mixed offer if they have a deficit in their cash position, and can also enjoy part of the tax benefit.

\section{METHODS AND ANALYSIS}

\section{A. Abnormal Returns.}

This paper used the standard event study methodology of Fuller[15], Netter and Stegemoller (2002), Dong, Hirshleifer, Richardson and Teoh (2006), Uddin and Boateng (2009). Take event window of $(-2$ to +2 days) and $(-10,+10)$ to calculate cumulative abnormal returns (CARs). More specifically, this study chose CAPM model as our benchmark and calculate abnormal returns. Gregory [16] (1997) stated that CAPM model could prevent from contamination caused by tendency noted by Franks [13] and

Harris (1989) and Limmack [21] (1991) where bidders outperform in the pre-acquisition period, with positive alpha.

This study take a 5-day $(-2,+2)$ for short event window and 21-day $(-10,+10)$ for a longer window, consistent with prior study of Doukas (1995); Gleason et al (2000); Gregory[16] and McCorriston (2005).

\section{1) Data}

The focus of this study is on all successful acquisitions by UK public firms announced between January 1993 and December 2000. And for the purpose of this research, merger is defined as an acquisition of equity where one company buy more than half of another company and control $90 \%$ of the target after the purchase. The sample is sourced from Thomson One Banker and DataStream. And deal characteristics, for example acquirer name, target nation, target industry, announcement date, payment methods, deal value and target statuses are drawn from Thomson One Banker.

The following criteria are used for the sample selection.

1. Acquirers are listing on the London stock exchange (LSE) and have at least 21 days of return data around the announcement day for short run analysis and 1-3 year return data for the long run analysis, and also should be nonfinancial public listed companies.

2. Deal value greater than 10 millions pound or more, as suggested by Gregory (1997) [17] that such cut-off can eliminate problems when acquires takeover small target companies and larger takeovers are economic significant and should be concerned more.

3. Companies have market data and financial statement available in the study over the $01 / 01 / 1993-31 / 12 / 2000$ period.

Table 1.1 presents the cumulative abnormal returns (CARs) of target and acquiring companies using CAPM model for $(-2,+2$ day) and $(-10,+10$ day) event window. First, look at the share price performance of both companies without considering payment methods. 
TABLE I. SHORT RUN CARS FOR BIDDERS AND TARGET FIRMS

\begin{tabular}{|c|c|c|c|c|}
\hline $\begin{array}{c}\text { Event } \\
\text { Window }\end{array}$ & \multicolumn{2}{|c|}{$\begin{array}{l}\text { 5Day } \\
(-2,+2)\end{array}$} & \multicolumn{2}{|c|}{$\begin{array}{c}\text { 21day } \\
(-10,+10)\end{array}$} \\
\hline & Target & Acquire & Target & Acquire \\
\hline $\operatorname{CARs}(\%)$ & $\begin{array}{l}12.32 * * * \\
(14.142)\end{array}$ & $\begin{array}{c}-0.002 \\
(-0.414)\end{array}$ & $\begin{array}{c}11.077 * * * \\
(8.995)\end{array}$ & $\begin{array}{c}-0.013 \\
(-1.427)\end{array}$ \\
\hline $\begin{array}{c}\text { Event } \\
\text { Window }\end{array}$ & \multicolumn{2}{|c|}{$\begin{array}{l}\text { 5Day } \\
(-2,+2)\end{array}$} & \multicolumn{2}{|c|}{$\begin{array}{c}\text { 21day } \\
(-10,+10)\end{array}$} \\
\hline & Target & Acquire & Target & Acquire \\
\hline \multicolumn{5}{|c|}{ Panel A: transaction financed with cash } \\
\hline CARs(\%) & $\begin{array}{c}12.706 * * * \\
(8.933)\end{array}$ & $\begin{array}{l}1.295 * * \\
(2.141)\end{array}$ & $\begin{array}{c}12.739 * * * \\
(7.759)\end{array}$ & $\begin{array}{c}0.943 \\
(1.044)\end{array}$ \\
\hline \multicolumn{5}{|c|}{ Panel B: transaction financed with stock } \\
\hline CARs(\%) & $\begin{array}{c}10.377 * * * \\
(6.622)\end{array}$ & $\begin{array}{l}-2.501 * * \\
(-2.218)\end{array}$ & $\begin{array}{c}12.661 * * * \\
(4.746)\end{array}$ & $\begin{array}{c}-5.758 * * * \\
(-2.580)\end{array}$ \\
\hline \multicolumn{5}{|c|}{ Panel C: transaction financed with mixed payment } \\
\hline $\operatorname{CARs}(\%)$ & $\begin{array}{c}13.336 * * * \\
(7.409)\end{array}$ & $\begin{array}{c}-1.347 \\
(-1.442)\end{array}$ & $\begin{array}{c}35.864 * * * \\
(6.597)\end{array}$ & $\begin{array}{c}-3.374 \\
(-0.718)\end{array}$ \\
\hline
\end{tabular}
Note: *,**,** Indicate statistical significance in 2-tailed test at the $10 \%, 5 \%$ and $1 \%$ percent level
respectively. The t-statistics for CARs shown in parentheses are computed follow Brown and Warner's(1985)dependent adjustment methodology.

Table 1.1 shows that target firms gain positive and higher abnormal returns around the announcement period than acquiring firms for both 5 day and 21 day event window. And significant positive CARs of target shareholders are statistically significant at $1 \%$ level. CARs for bidders are small negative and insignificant. These results are consistent with previous findings that target companies earn large and significant positive returns. Bidders, however, earn small and insignificant positive return, or small and insignificant negative returns (Sudarsanam, 2003) [25]. Barnes (1984)'s [2] results also show negative and insignificant returns on month zero.

Looking at longer event window, positive cumulative abnormal returns received by both target firms and bidders decreased, these results illustrate the efficiency of stock market, where share prices reflect the new information on merger announcement immediately.

Why acquiring firms suffer loss in the short run, it may suggest that shareholders of acquiring companies may know the merger intention before the announcement and they regards such activity as bad investment, this can lead to share price decrease and result in overall loss of shareholder wealth.

The CARs difference of the two event window suggest the inefficiency of stock market, the conclusion is consist with Barnes (1984) [2], Dodds and Quel (1985) [9] and Limmack [22] (1991), and Firth (1980) [11] conclude differently, where newly information coming to the market take time to have effect on the stock market.

Then move to the CARs received by shareholders of target and acquires of these two event windows in terms of payment methods.

Starting with cash acquisitions, Panel A of table 1.1 present abnormal returns for target and acquiring companies use cash as financing method. Shareholders of bidding companies earn small positive and significant CARs $(1.295 \%)$ at $5 \%$ significant level. And for longer event window, the CARs of 21 day is small and insignificant. However, target shareholders earn significant positive cumulative returns of $12.706 \%$ and $12.739 \%$ respectively. Both results are significant at $1 \%$ level. And it is worth noticing CARs largely increases as event window expand.

Panel B of table 1.1 displays the CARs for target and bidders when stock offer used as payment method. Results show target shareholders' experience positive and significant cumulative abnormal returns above $12 \%$ for both 5 day and 21 day event window. Both positive returns are statistically significant at $1 \%$ level. For acquiring companies, results are quite different. Where negative cumulative abnormal returns received over the 5 day and 21 day event window are significant at $5 \%$ and $1 \%$ significant level.

Finally, Panel C illustrates results for target and acquirers adopt mixed payment as a financing method for mergers and acquisitions. Result shows largely positive cumulative abnormal returns for target shareholders. Results are statistically significant at $1 \%$ level. Shareholder of acquiring firms receives insignificant negative gains on both event window when mixed payment is used. These results may lead to unfavorable of such method by acquiring firms. And most importantly, shareholders of acquiring companies receive even more negative abnormal returns when stock payment is used. Therefore risk-aversion firms prefer mixed payment, as they will loss more if stock financing is used (Uddin and Boateng, 2009) [25]. There are limited studies for mixed payment in mergers and acquisitions.

The results on all three payments are consistent with findings of Barnes (1984) [2], Gregory (1997) [17], Sudarsanam[25], Holl [20] and Salami (1996) and Sudarsanam, and Mahate (2003). Their empirical evidence illustrate that pure cash payment experience greater abnormal returns than stock exchange payment, which is opporsite to Dodds and Quek(1985)'s findings 9].

Overall, we can see that target shareholders receive more than shareholders of acquiring firms, they are winners in M\&As when cumulative abnormal return is compared. And among all three payment method, cash acquisitions generate 
significant massive returns for shareholders. For target companies, about $80 \%$ abnormal returns are generated for the 5 day event window generated from announcement date and two days following the merger announcement. This result suggests that shareholders of target firms prefer cash acquisitions, they can benefit more if cash is used to pay the merger. To conclude, target shareholders earn positive abnormal returns in the short run merger transactions and cash acquisitions experience highest abnormal returns for target shareholders. This results consistent with findings of Ruback (1977), Kummer and Hoffmeister (1978), Jarrell and Bradley (1980), Asquith, Bruner, and Mullins (1983) [1], Bradley, Desai, and Kim (1988) and Franks and Harris (1989) [14] show positive and significant values for target companies.

Panel B of table 1.1 displays the CARs for target and bidders when stock offer used as payment method. Results show target shareholders' experience positive and significant cumulative abnormal returns above $12 \%$ for both 5 day and 21 day event window. Both positive returns are statistically significant at $1 \%$ level. For acquiring companies, results are quite different. Where negative cumulative abnormal returns received over the 5 day and 21 day event window are significant at $5 \%$ and $1 \%$ significant level.

Finally, Panel C illustrates results for target and acquirers adopt mixed payment as a financing method for mergers and acquisitions. Result shows largely positive cumulative abnormal returns for target shareholders. Results are statistically significant at $1 \%$ level. Shareholder of acquiring firms receives insignificant negative gains on both event window when mixed payment is used. These results may lead to unfavorable of such method by acquiring firms. And most importantly, shareholders of acquiring companies receive even more negative abnormal returns when stock payment is used. Therefore risk-aversion firms prefer mixed payment, as they will loss more if stock financing is used (Uddin and Boateng, 2009) [25]. There are limited studies for mixed payment in mergers and acquisitions.

From the above results, we can conclude that shareholders of acquiring companies gain substantial negative returns of $-5.758 \%$ for 21 day and $-2.5 \%$ for 5 day event window when stock payment is used in takeovers. Therefore, stock financing is least preferred for bidders in mergers and acquisitions. For the total sample 237 acquirers, 60 out of 237 bidders use stock financing method, and the reason of negative abnormal returns for bidders may result from insufficient fund for cash offer or overvaluation of bidders share price, as more information available in the market, share price will be adjusted when signaling overvaluation of acquiring firms. However, target shareholders may prefer stock financing as such payment methods do generate significant positive abnormal returns for target companies.

All results in Table 1.1 are consistent with findings of Jensen and Ruback (1983), Netter (1988) show value creation for shareholders overall, but those gains mainly contribute to target shareholders.

\section{CONCLUSION}

This paper examines mergers and acquisitions postperformance of UK public listed companies during 19932000. Event study applied in this study, CARs has been used to observe abnormal return for short-run analysis. Results show that abnormal returns for bidders are negative in the short run, while target shareholders receive positive returns.

Stock market inefficiency may lead to bidders' share price over or undervalued. In general, when price of acquiring firms are undervalued, they would prefer cash payment and earn positive CARs after M\&As. To explain the insignificant negative CARs of sub-group of cash payment, one reason could be the consideration of heavy ownership in public traded firms in the UK (Faccio and Land, 2002) [9], instead of the reason on acquiring firms being undervalued.

Based on the empirical results, most conclusions are consistent with evidence of the previous researches papers, however, there are some limitations of this study.

For further study, multivariate analysis can be conducted to examine the causation factors' impact on both target and acquiring firms' share price. As noted by Draper and Paudyal (2008), univariate analysis fails to illustrate the mutual effect of alternative variables on share price change.

\section{ACKNOWLEDGMENT}

Funding for this research was provided by National Natural Science Foundation of China under grants 71762033. The facilitation from international collaborative program and cooperation with Charles Sturt University in Australia is gratefully acknowledged. The assistance of Dr. Eshref Trushin, Professor Mark Frost and Antony Bush and comments from an associate editor and two anonymous reviewers are also acknowledged.

\section{REFERENCES}

[1] P. Asquith, R. Bruner, and D. Mullins, "The gains of bidding firms from merger," Journal of Financial Economics, vol. 11, 1983, pp. 121-139.

[2] P. Barnes, "The Effect of a Merger on the Share Price of the Attacker, Revisited," Accounting \& Business Research. IS-S7, 1985, pp. 4S-49.

[3] E.L. Black, J.M. Guo, and J.M.T. Kuo, "Do UK mergers create shareholder value? UK evidence," 2010.

[4] M. Bradley, A. Desai, and E.H. Kim, "Synergistic gains from corporate acquisitions and their division between the stockholders of target and acquiring firms," Journal of Financial Economics, vol. 21 , 1983, pp. 3-40

[5] S. Brown, and J. Warner, "Using daily stock returns (the case of event studies)," Journal of Financial Econmics, vol. 14, 1985, pp. 3-31.

[6] R.F. Bruner, "Does M\&A pay? A survey of evidence for the decision maker," Journal of Applied Finance, vol. 12, Spring/Summer, 2002.

[7] J.M. Campa, and I. Hernando, "Shareholder value creation in European M\&As,” European Financial Management, vol. 10, 2004, pp. 47-81.

[8] De Pamphilis, Mergers, Acquisitions and Other Restructurings, 6th Edition, McGraw-Hill Irwin, 2012

[9] J.C. Dodds, J.P. Quek, and J.P, "Effect of mergers on the share price movement of the acquiring firms: A UK study," Journal of Business Finance \& Accounting, vol. 12, 1985, pp. 285-296. 
[10] M. Faccio, and R.W. Mazulis, "The choice of payment method in European mergers and acquisitions," Journal of Finance 60, 2005, pp. 1345-1388.

[11] Firth, and M. Takeovers, "shareholder returns, and the theory of the firm.Quarterly," Journal of Economics, 1980, pp. 235-260.

[12] M. Fishman, "Preemptive bidding and the role of the medium of exchange in acquisitions," Journal of Finance, 1989, pp. 41-57.

[13] M. Fonseka, L.P. Samarakoon, and G.L. Tian, "Equity financing capacity and stock return: Evidence from China," Journal of International Financial Market, Institution and Money, vol. 22, 2012, pp. 1277-1291.

[14] J. Franks, and R.S. Harris, "Shareholder wealth effects of corporate takeovers: The U.K. experience 1955-1985," Journal of Financial Economics, vol. 23, 1989, pp. 225-249.

[15] R.V. Frederikslust, and H. Westdijk, "Shareholder wealth effects of mergers and acquisitions," working paper, Erasmus Universiteit Rotterdam, 2005, pp. 1-35.

[16] K. Fuller, L. Netter, and M. Stegemoller, "What do returns to acquiring firms tell us? Evidence from firms that make many acquisitions," Journal of Finance, 57, 2002, pp. 1763-1793.Gregory, A. \& McCorriston, S. "Foreign acquisitions by UK limited companies: short- and long-run performance," Journal of Empirical Finance, vol. 12, 2005, pp. 99-125.

[17] P. Healy, K. Palepu, R. Ruback, "Does corporate performance improve after mergers?” Journal of Financial Economics,31(2), 1992, pp. $135-175$.

[18] C. Higson, and J. Elliott, "Post-takeover returns: The UK evidence," Journal of Empirical Finance. Hsuan Shih Lee, W.C. Ching, Z. Joe, "Super-efficiency DEA in the presence of infeasibility," European Journal of Operational Research, vol. 212, 1998, pp. 141-147.

[19] P. Holl, and D. Kyriazis, "Wealth creation and bid resistance in UK takeover bids," Strategic Management Journal, vol. 18, 1997, pp.483498.

[20] V.A. Kennedy, and R.J. Limmack, "Takeover Activity, CEO Turnover, and the Market for Corporate Control," Journal of Business Finance and Accounting, vol. 23, 1996, pp. 267-285.
[21] R.J. Limmack, "Corporate mergers and shareholder wealth effects: 1977-1986," Accounting and Business Research, vol. 21, 1991, pp. 239-252.

[22] P. Malatesta, "he wealth effects of merger activity and the objective function of merging firms," Journal of Financial Economics, 11(1-4), 1983, pp.155-181.

[23] F. Rossi, "The Post-Merger Performance: Evidence From Italy," Editorial Board Members, vol. 11, 2012, pp. 931-945.

[24] S. Sudarsanam, and A.A. Mahate, "Glamour acquirers, method of mayment and most - acquisition Performance: The UK Evidence," Journal of Business Finance \& Accounting, vol. 30, 2003, pp. 299342.

[25] M. Uddin, and A. Boateng, "An analysis of short run performance of cross-border mergers and acquisitions: evidence from the UK acquiring firms," Review of Accounting and Finance, vol. 8, 2009, pp. 431-453.

[26] J. Weston, Fred. and S.C. Weaver, "mergers and acquisitions," 2001 